\title{
Penerapan Animaker dalam Pembuatan Iklan Produk UMKM Berbasis Animasi
}

\author{
Dian Pratiwi'1, Ahmad Zuhdi², Ratna Shofiati³, Reymartin Reza Pratama4,, Hafiz Adi \\ Wijaya $^{5}$ \\ 1,2,3,4,5Universitas Trisakti, Indonesia \\ e-mail: 1dian.pratiwi@trisakti.ac.id, ${ }^{2}$ zuhdi@trisakti.ac.id, ${ }^{3}$ ratna@trisakti.ac.id
}

\begin{abstract}
Abstrak
Makin maraknya beberapa media promosi membuat persaingan penjualan produk semakin tinggi pula. Jenis media konvensional pun mulai ditinggalkan dan banyak beralih ke media teknologi seperti videotron atau layar-layar LCD. Penggunaan media tersebut tentunya perlu didukung dengan isi konten promosi yang menarik pula dalam mengiklankan produk, terutama produk-produk yang diperkenalkan oleh para UKM. UKM di Indonesia sering kali menghadapi berbagai masalah seperti promosi, pemasaran dan penjualan. Inilah yang kemudian akan coba diatasi dalam kegiatan PKM kali ini, dimana akan dibuat sebuah pelatihan untuk para pelaku UKM dalam mengembangkan konten iklan berbasis animasi guna mempromosikan produk-produk yang dijual oleh mereka. Pelatihan ini pada tanggal 16 Mei 2020 telah berlangsung terdiri dari dua sesi, dimana sesi pertama adalah memperkenalkan software online Animaker untuk membuat iklan animasi. Sesi kedua adalah sesi praktek, dimana secara daring para peserta diberikan petunjuk tahap demi tahap dalam membuat iklan animasi, dengan kasus iklan penjualan makanan \& minuman. Sebagai tambahan akhir sesi, kegiatan ini juga memberikan sesi kuis berhadiah dengan menggunakan aplikasi Kahoot, kepada para peserta untuk menjawab beberapa pertanyaan seputar materi kegiatan. Berdasarkan hasil evaluasi dari 8 peserta yang hadir purna waktu melalui kuisioner, diketahui bahwa sebanyak $87.5 \%$ peserta menilai pelatihan ini mudah dipahami, 100\% peserta menilai pembicara sudah menjelaskan materi cukup baik, 100\% peserta mengatakan pengaturan waktu sudah tepat, dan sebanyak $62.5 \%$ dari peserta akan mengimplementasikan hasil pelatihan tersebut ke dalam toko/usaha yang mereka jalankan. Dengan demikian, dapat disimpulkan bahwa dari kegiatan pembuatan iklan produk berbasis animasi ini telah memberikan manfaat yang cukup terlihat dan berhasil diterima dengan baik oleh peserta
\end{abstract}

\section{Kata Kunci: Animaker, Animasi, Iklan, Kahoot}

\begin{abstract}
More and more promotional media make product sales competition higher as well. Conventional media types are starting to open and many are turning to technological media such as Videotron or LCD screens. The use of this media needs to be supported by attractive promotional content as well as promoting products, products introduced by SMES. SMEs in Indonesia often face various problems such as promotion, marketing, and sales. This is what will then be addressed in this PKM activity, where training will be made for SME
\end{abstract}


entrepreneurs in developing animation-based advertising content to improve the products sold by them. The training was completed on May 16, 2020, consisting of two sessions, while the first session introduced the Animaker online software to create animated advertisements. The second session was a practical session, where there were participants who dared to be given instructions to create an animation, with the case of an advertisement for food $\mathcal{E}$ beverage sales. In addition to the end of the session, this activity also provides a quiz session with prizes using the Kahoot application, for participants to answer questions about the activity material. Based on the evaluation results of 8 participants who were present through the questionnaire, $87.5 \%$ of the participants were easy to understand, $100 \%$ of the participants agreed that they explained the material well enough, 100\% of the participants said that the timing was right, and $62.5 \%$ the participants will implement the training in the shop/business they run. Thus, it can be concluded that the activity of making advertising based products has provided benefits that are quite visible and successfully received by the participants

\section{Keywords: Animaker, Animation, Advertising, Kahoot}

\section{Pendahuluan}

Teknologi kini sudah semakin pesat, dan hampir semua bidang telah memanfaatkannya untuk mendukung rutinitas sehari-hari. Salah satunya adalah bidang penjualan atau sales. Dalam meningkatkan minat pembeli terhadap produk, para penjual membutuhkan promosi yang menarik dan berbeda dari yang lain. Makin maraknya beberapa media promosi membuat persaingan penjualan produk semakin tinggi pula. Jenis media konvensional seperti pamflet, poster, banner pun mulai ditinggalkan dan banyak beralih ke media teknologi seperti videotron atau layar-layar LCD. Penggunaan LCD ata Videotron membuat sarana promosi jadi nampak lebih menarik, efisien, dan efektif. Penggunaan media tersebut tentunya perlu didukung dengan isi konten promosi yang menarik pula dalam mengiklankan produk, terutama produk-produk yang diperkenalkan oleh para UKM (Usaha Kecil dan Menengah). Usaha Kecil dan Menengah merupakan salah satu bidang yang memberikan kontribusi yang signifikan dalam memacu pertumbuhan ekonomi Indonesia. Hal ini dikarenakan daya serap UKM terhadap tenaga kerja yang sangat besar dan dekat dengan masyarakat berperekonomian kecil. Tetapi UKM di Indonesia sering kali menghadapi berbagai masalah seperti promosi, pemasaran dan penjualan. Inilah yang kemudian akan coba diatasi dalam kegiatan PKM kali ini, dimana akan dibuat sebuah pelatihan untuk para pelaku UKM dalam mengembangkan konten iklan berbasis animasi guna mempromosikan produkproduk yang dijual oleh mereka. Dengan adanya pelatihan ini, diharapkan selain dapat memberikan pengetahuan tentang cara membuat iklan produk berbasis animasi, juga mampu meningkatkan daya tarik promosi produk para pelaku UKM, khususnya pelaku UKM di wilayah Jakarta Barat dan Tangerang.

Berdasarkan survey yang pernah dilakukan oleh tim PKM ke wilayah Jakarta Barat dan Tangerang, para pelaku UKM memiliki beberapa masalah yang berkaitan dengan usahanya seperti Belum memiliki media promosi yang memadai, karena 
terkendala biaya yang cukup besar untuk mengiklankan produk mereka. Kurangnya pengetahuan untuk melakukan promosi dengan menggunakan teknologi komputer, terutama internet. Kurangnya pengetahuan untuk membuat promosi yang menarik, terutama dalam bentuk animasi.

Dalam mencari solusi dari permasalahan yang ada, tim melakukan uji coba aplikasi daring yang dapat digunakan dengan mudah untuk para peserta PKM yang mayoritas belum pernah mengikuti pelatihan pembuatan iklan produk berbasis animasi. Aplikasi yang diuji coba oleh tim dimulai Animatron, Powtoon, hingga Animaker. Setelah mempelajari dan menguji hasil iklan yang dibuat, penggunaan tools online Animaker dipilih untuk media yang akan digunakan oleh peserta saat membuat iklan animasi. Kemudian, dalam memudahkan peserta mempelajari Animaker, tim menyediakan modul Animaker berbentuk file pdf yang dapat mereka langsung coba. Tim juga memberikan contoh pembuatan iklan penjualan makanan \& minuman delivery order pada sesi pelatihan studi kasus, untuk memudahkan mereka dalam mencontoh luaran iklan pada penjualan produk mereka sendiri. Diharapkan, dengan adanya kegiatan ini dapat memberikan cara beriklan yang baru dalam memasarkan produk, mengurangi pemakaian media iklan konvensional, sehingga dapat lebih menghemat pengeluaran, dan mengurangi kesulitan-kesulitan yang timbul dalam memasarkan produk UMKM peserta.

\section{Metode}

Kegiatan pengabdian kepada masyarakat ini telah sukses diselenggarakan pada hari Sabtu, 16 Mei 2020, secara daring (dikarenakan masa Pembatasan Sosial Berskala Besar/PSBB akibat dari pandemic Covid-19) melalui sarana Google Meet kepada 8 peserta UMKM dari 20 peserta yang teregistrasi. Pelaksanaan dimulai pukul 09:00 hingga 12:20, yang diawali dengan persiapan koneksi internet dan materi panitia pada pukul 08: 45. Berikut adalah jadwal acaranya:

\begin{tabular}{|c|c|c|}
\hline Waktu & Tabel 1. Jadwal Kegiatan PKM & PIC \\
\hline 08:45-09:00 & Persiapan acara PKM & TIM \\
\hline 09:00-09:10 & $\begin{array}{l}\text { Pembukaan \& sekilas informasi mengenai } \\
\text { Jurusan \& kegiatan PKM }\end{array}$ & $\begin{array}{l}\text { Dian Pratiwi, Ratna Shofiati } \\
\& \text { moderator (Yunia } \\
\text { Ningsih) }\end{array}$ \\
\hline 09:10-10:00 & $\begin{array}{l}\text { Sesi 1: Pengenalan Animasi \& Animaker } \\
\text { untuk pembuatan iklan animasi yang } \\
\text { menarik }\end{array}$ & Hafiz Adi Wijaya \\
\hline $10: 00-11: 30$ & $\begin{array}{l}\text { Sesi 2: Praktek Animaker (studi kasus: } \\
\text { membuat iklan penjualan makanan } \\
\text { delivery order) }\end{array}$ & Reymartin Reza Pratama \\
\hline $11: 30-11: 50$ & Tanya-Jawab Materi & TIM \\
\hline $11: 50-12: 00$ & Quiz Berhadiah & Moderator \\
\hline 12:00 - selesai & $\begin{array}{l}\text { Pengisian Kuisioner Evaluasi \& Penutupan } \\
\text { acara PKM }\end{array}$ & Ahmad Zuhdi \& Moderator \\
\hline
\end{tabular}


Sebelum pelaksanaan dimulai, seminggu sebelumnya panitia telah berlatih dalam mempresentasikan materi yang telah dipersiapkan, sambil menguji coba studi kasus dengan menjalankan Animaker.

Satu hari menjelang pelaksanaan, tim mengirimkan link Google Meet yang akan digunakan untuk pertemuan ke masing-masing peserta melalui WhatsApp, sambil mengingatkan mereka untuk hadir 10 menit sebelumnya . Link tersebut adalah sebagai berikut:

To join the video meeting, click this link: https:// meet.google.com/xco-vdoprve

Otherwise, to join by phone, dial +1 413-459-4355 and enter this PIN: 121582 $758 \#$

Pada pukul 09:10 kemudian acara dibuka oleh Ratna Shofiati, selaku perwakilan dari ketua Tim PKM yang belum dapat hadir tepat waktu karena adanya gangguan sinyal. Setelah acara dibuka, moderator mengambil alih acara dimana dilanjutkan ke acara sesi materi pertama yaitu pengenalan Animasi dan Animaker.

Animasi merupakan simulasi pergerakan yang dibuat dari sekumpulan gambar. Definisi lainnya yaitu sebuat metode penangkapan gambar/fotografi yang berasal dari lukisan/gambar, model untuk membuat ilusi pergerakan secara sekuensial (Maio, A, 2020). Ada beberapa tipe animasi, seperti (Masruroh, 2019):

1) Animasi Tradisional

Animasi tradisional atau cel animation merupakan objek yang digambar dengan menggunakan kertas transparan seluloid, dimana untuk menciptakan animasi, pelukis harus menggambar frame per frame (Guha, 2014).

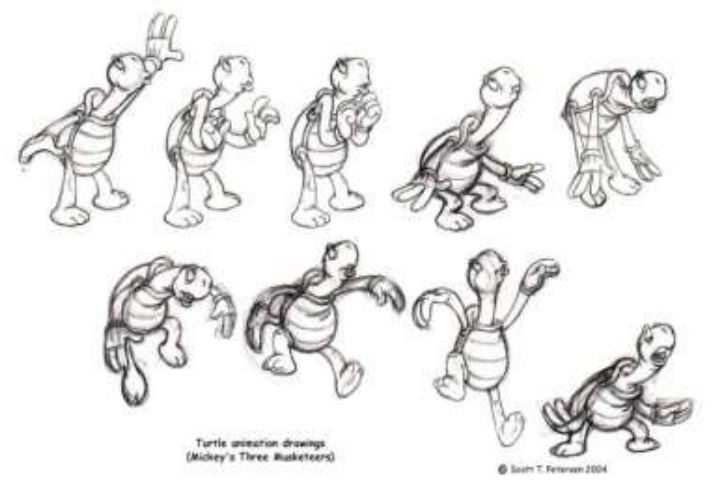

Gambar 1. Contoh Animasi Tradisional (Anonymous, 2014)

2) Animasi 2D (berbasis Vektor)

Merupakan pengembangan dari animasi tradisional, yang dihasilkan dengan menggunakan software animasi 2D seperti Macromedia Flash, Corel Rave, Adobe After Effect, dan lainnya (Setiawan dan Ulhaq, 2015). Contohnya berbagai hasil film produksi Disney, seperti Aladdin, Beauty and The Beast, dan lain-lain. Bentuk lain dari animasi 2D yang bukan merupakan animasi tradisional adalah animasi berbasis vektor. Perbedaannya adalah, animasi berbasis vektor bukan terdiri dari piksel-piksel, namun dibentuk dari garis primitif. 
3) Animasi 3D

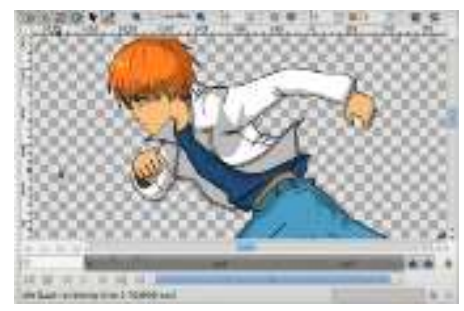

Gambar 2. Contoh Animasi 2D berbasis Vektor

Merupakan seni yang menggunakan gerakan untuk membawakan karakter ke dalam ruang 3 dimensi (Williams, R., 2012). Beberapa software yang dapat digunakan untuk membuat animasi 3D yaitu: 3D Studio Max, Maya, Poser, Bryce, Vue, Cinema 4D, Blender (Setiawan, A.P. dan Ulhaq, M.M.Z., 2015)

4) Motion Graphics

Merupakan suatu metode yang menyediakan cara untuk membuat gambar dapat bergerak. Suatu motion graphic memiliki unsur: eyecatcher, groups, managing time, asymmetry creates tension, repetitions for recognition, natural and reasonable (Fecher, T., 2017). Contohnya seperti berikut (Tonnu, T., 2020):

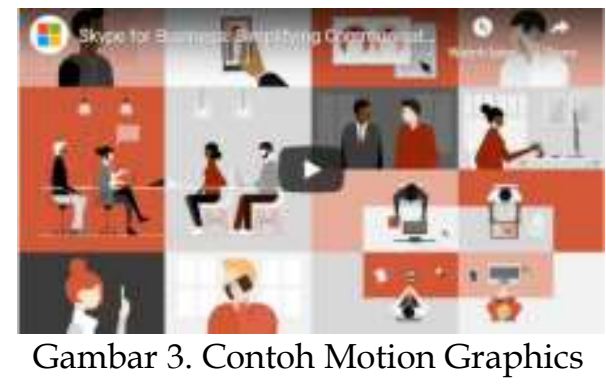

5) Stop Motion (Masruroh, F., 2019)

Animasi jenis ini menggunakan beberapa foto objek sebagai model dengan perbedaan posisi pada tiap objeknya, yang kemudian foto-foto tersebut disatukan menjadi video klip. Dengan animasi ini menjadikan adegan yang sulit dilakukan dapat terjadi. Contoh:

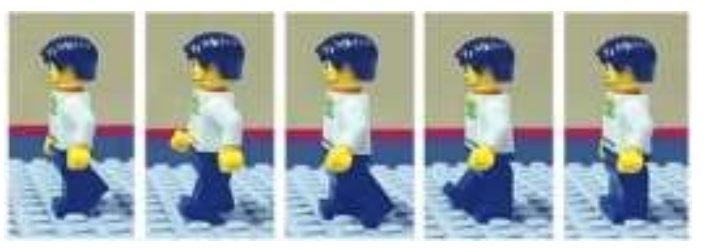

Gambar 4. Contoh Stop Motion

Menurut (Setiawan, A.P. dan Ulhaq, M.M.Z., 2015), animasi computer dapat dikategorikan menjadi:

1. Computer Assisted Animation

Merupakan prosedur untuk mengkomputerisasikan proses animasi tradisional menggunakan gambaran tangan. Komputer digunakan untuk pewarnaan, penerapan virtual kamera dan pengaturan data.

2. Computer Generated Animation

Biasanya digunakan untuk membuat animasi 3D melalui program/aplikasi komputer seperti Maya, Autocad, 3DMax. 
Sedangkan Animaker merupakan perangkat lunak video animasi berbasis cloud yang akan sangat berguna jika ingin membuat video professional berkualitas studio (Williams, R., 2012)( Raghav., 2014).

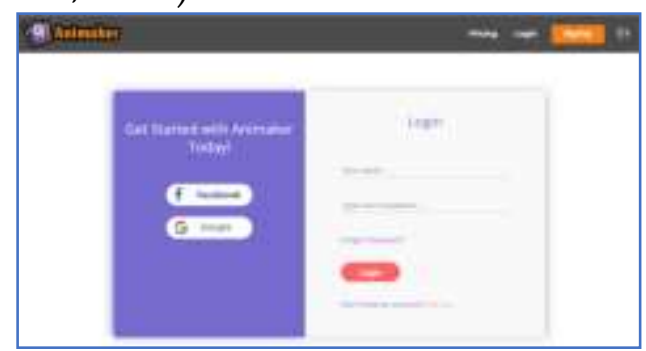

Gambar 5. Tampilan Aplikasi Animaker

Kedua materi tersebut dibawakan oleh mahasiswa dari Program Studi Sistem Informasi yaitu Hafiz Adi Wijaya.

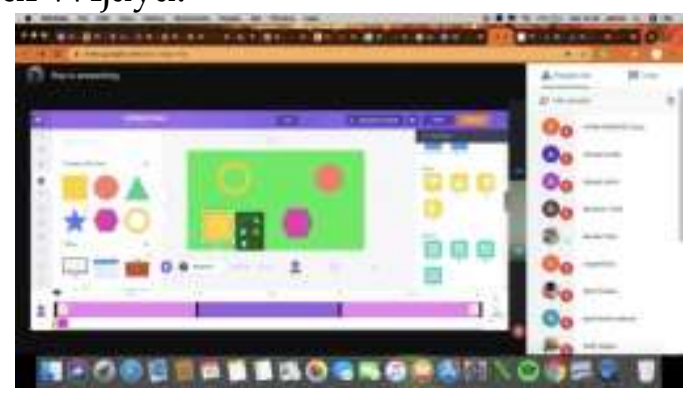

Gambar 6. Materi Animaker

Setelah selesai, kemudian langsung dilanjutkan ke sesi materi kedua yaitu praktek step-by-step membuat iklan produk penjualan makanan/minuman delivery order dengan aplikasi Animaker secara online, yang dibawakan oleh mahasiswa dari Program Studi Informatika yaitu Reymartin Reza Pratama. Animaker sendiri bisa diakses di url: https://www.animaker.com/.

Dari hasil pelatihan sesi kedua, video iklan animasi yang berhasil dibuat adalah seperti berikut ini tampilannya (frame per frame):
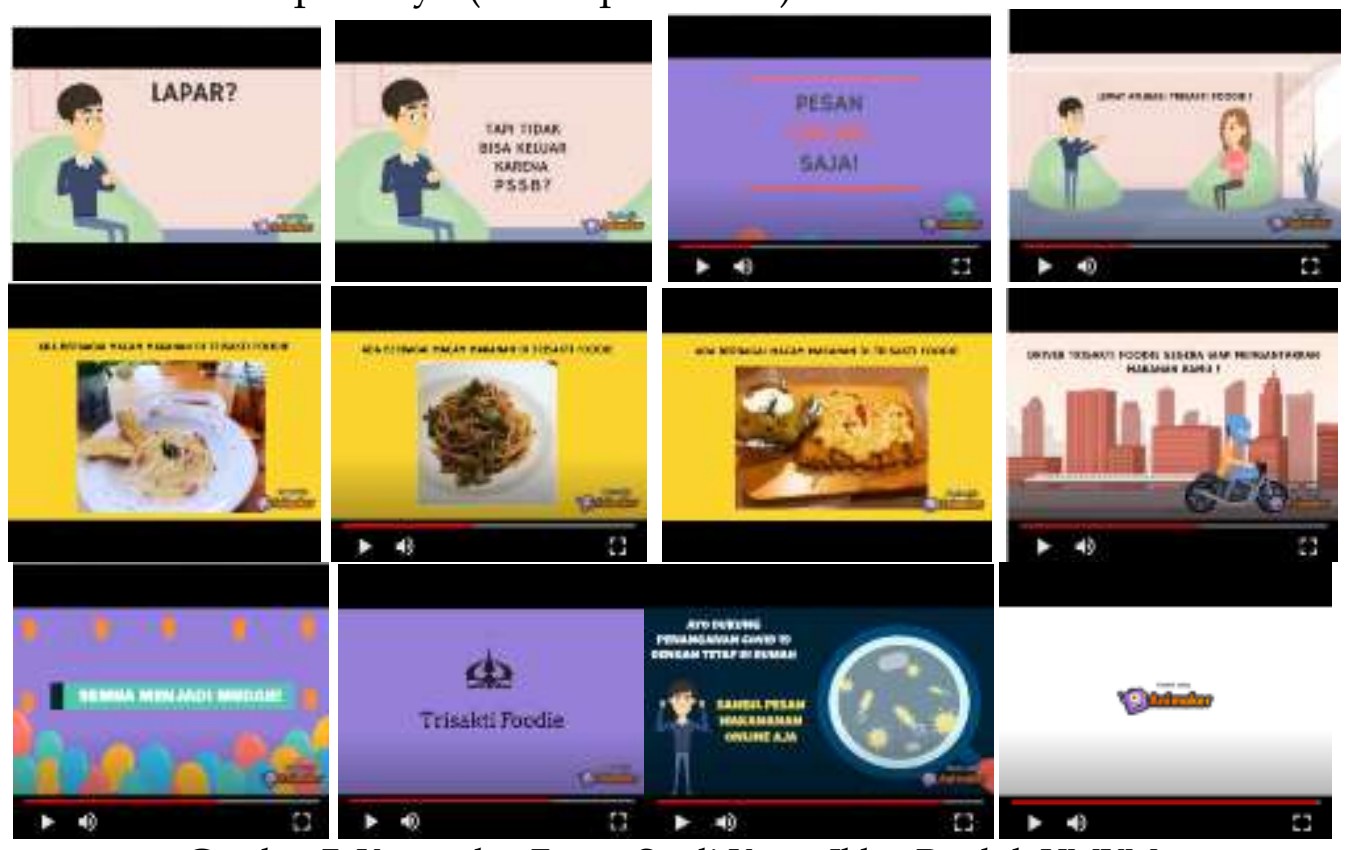

Gambar 7. Kumpulan Frame Studi Kasus Iklan Produk UMKM 
Setelah sesi studi kasus / sesi kedua selesai, acara dilanjutkan dengan sesi Tanyajawab. Beberapa peserta ternyata antusias menanyakan tentang cara penggunaan dan fungsi di menu aplikasi Animaker lebih detail. Setelah sesi Tanya-jawab selesai, quiz berhadiah pun dilangsungkan. Dimana quiz tersebut menggunakan aplikasi online Kahoot untuk meletakkan 5 pertanyaan yang telah disediakan panitia. Panitia menggunakan url berikut ini untuk mempersiapkan quiz berhadiah: https://kahoot.com/. Sedangkan untuk peserta yang akan mengikut quiz, dapat mengakses url berikut: https://kahoot.it/.

Kahoot sendiri adalah platform pembelajaran berbasis permainan/game yang mudah untuk dibuat, dibagikan dan memainkan game pelajaran atau quiz dalam hitungan menit. Kahoot dapat diimplementasikan dalam lingkungan sekolah, kerja/kantor, rumah, atau belajar mandiri (Anonymous., 2020). Berikut adalah contoh aplikasi Kahoot:

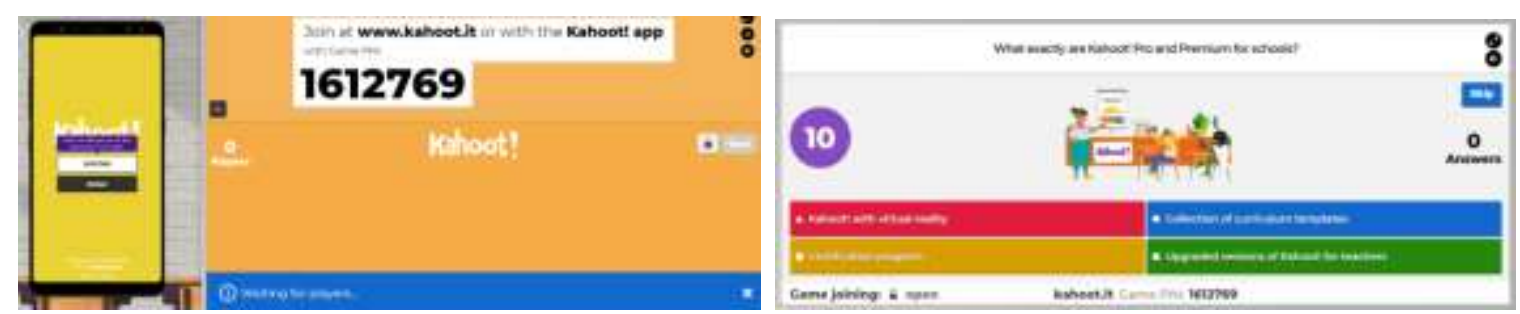

Gambar 8. Tampilan-Tampilan Aplikasi Kahoot

Dalam sesi terakhir, sebelum penutupan acara. Peserta diminta untuk mengisi kuisioner evaluasi terlebih dulu, dengan url berikut: https://bit.ly/evaluasi_animasi.

Pelaksanaan kegiatan ini dapat dikatakan berjalan cukup lancar dan memiliki feedback yang positif dari para peserta. Hal tersebut dapat dilihat dari salah satu testimonial yang didapat tim PKM dari peserta, berikut ini:

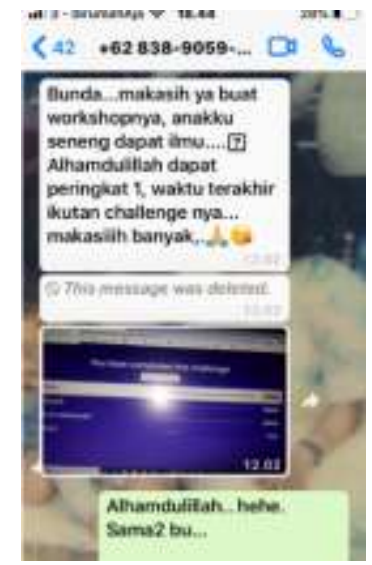

Gambar 9. Testimonial Peserta PKM

Dan berdasarkan hasil evaluasi dari pengisian kuisioner, $87.5 \%$ peserta menyatakan keinginannya untuk bisa mengikuti pelatihan seperti ini lagi jika diadakan kembali. Dengan demikian, kegiatan PKM 'Pelatihan Pembuatan Iklan Produk berbasis Animasi' ini diharapkan akan dapat dilaksanakan kembali dengan peserta yang lebih banyak, lebih menarik, dan lebih baik lagi. 


\section{Hasil dan Pembahasan}

Sebelum dilaksanakan kegiatan pengabdian kepada masyarakat ini, tim membuat 2 kuisioner untuk para peserta, dimana kuisioner pertama (dilakukan saat registrasi) guna menangkap identitas dan latar belakang para peserta. Sedangkan kuisioner kedua, dilakukan saat kegiatan PKM selesai dilaksanakan (dibagikan sebelum penutupan acara ). Berikut adalah hasil dari evaluasi kegiatan yang dirangkum dari pengisian kuisioner para peserta:
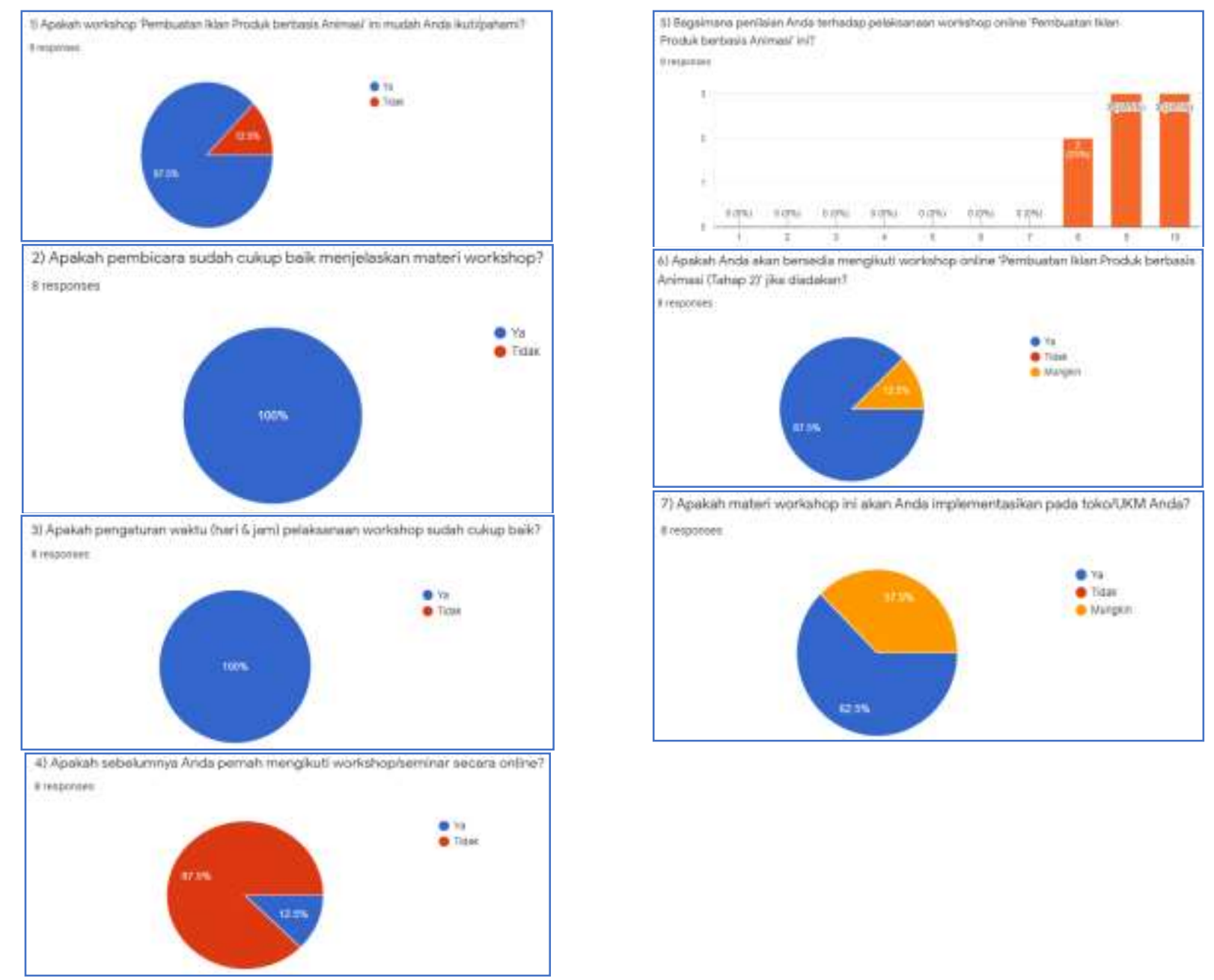

Gambar 10. Kumpulan Grafik Evaluasi Kegiatan

Berdasarkan grafik-grafik pada gambar 10 di atas, dapat disimpulkan bahwa kegiatan PKM yang dilakukan secara daring pertama kali telah berhasil dilaksanakan dengan baik dan lancar, sesuai dengan target perencanaan kegiatan PKM di Jurusan Teknik Informatika Universitas Trisakti. Kemudian jumlah peserta yang mendaftar untuk mengikuti pelatihan ini melebihi ekspektasi, dimana dari 20 peserta batas maksimal jumlah peserta yang diperbolehkan, terdapat lebih dari 30 peserta yang mendaftar. Sehingga tim PKM harus menyaring peserta, dimana 20 peserta diambil dari peserta yang mendaftar lebih dulu. Selain itu, kegiatan ini berhasil mendapat tanggapan yang baik dari komunitas pengusaha ibu-ibu di 
Tangerang Selatan, dimana PKM ini diharapkan akan dapat dilangsungkan kembali di lingkungan Universitas Trisakti, dan tidak lagi secara daring

\section{Simpulan dan Rekomendasi}

Kesimpulan yang didapat dari kegiatan PKM 'Pembuatan Iklan Produk berbasis Animasi' ini adalah:

1. Kegiatan pelatihan Pembuatan Iklan Produk berbasis Animasi ini telah berhasil dilaksanakan dengan baik, dengan jumlah peserta yang hadir secara daring sebanyak 8 orang dari 20 peserta yang mendaftar. Hal ini terlihat pada hasil evaluasi kuisioner dengan rentang nilai 1 (sangat buruk) - 10 (sangat baik), sebanyak 3 peserta menyatakan nilai 10, 3 peserta menyatakan nilai 9, dan 2 peserta menyatakan kegiatan ini bernilai 8. Sehingga didapat penilaian pelaksanaan rata-rata kegiatan PKM ini adalah bernilai 9 atau nyaris sempurna.

2. Berdasarkan hasil evaluasi dari 8 peserta yang hadir purna waktu melalui kuisioner, diketahui bahwa sebanyak $87.5 \%$ peserta menilai pelatihan ini mudah dipahami, $100 \%$ peserta menilai pembicara sudah menjelaskan materi cukup baik, $100 \%$ peserta mengatakan pengaturan waktu sudah tepat, dan sebanyak $62.5 \%$ dari peserta akan mengimplementasikan hasil pelatihan tersebut ke dalam toko/usaha yang mereka jalankan. Dengan demikian, dapat disimpulkan bahwa dari kegiatan pembuatan iklan produk berbasis animasi ini telah memberikan manfaat yang cukup terlihat dan berhasil diterima dengan baik oleh peserta

Sedangkan untuk saran yang dapat diberikan dari hasil kegiatan ini adalah perlu adanya perbaikan dalam sistem atau prosedur registrasi kegiatan agar dikemudian hari, peserta yang mendaftar akan tetap konsisten dan tepat waktu dalam mengikuti pelatihan secara daring.

\section{Ucapan Terima Kasih}

Artikel ilmiah ini ditujukan untuk mengenang Almh. ibunda Sri Mulyani, yang telah banyak memberikan dukungan dan semangatnya kepada penulis untuk menyelesaikan kegiatan PKM ini sebaik-baiknya.

\section{Daftar Pustaka}

Maio, A. 2020. What is Animation? Definition and Types of Animation. Url: https://www.studiobinder.com/blog/what-is-animation-definition/

Guha, S. 2014, Computer Graphics Through OpenGL : From Theory to Experiments, 2nd Edition. CRC Press: USA

Masruroh, F. 2019. Ingin Jadi Animator? Kenali dulu Jenis Animasinya. BPPTIK. Url: https://bpptik.kominfo.go.id/2019/12/26/7562/ingin-jadi-animator-kenalidulu-jenis-animasinya/

Setiawan, A.P. dan Ulhaq, M.M.Z. 2015. Animation. Url: https://www.academia.edu/35932996/E-book_Animasi.pdf 
Anonymous. 2014. 2D Animation. Animation NL. Url: http://www.animationnl.ca/2d-animation

Williams, R. 2012. The Animator's Survival Kit: A Manual of Methods, Principles, and Formulas for Classical, Computer, Games, Stop Motion and Internet Animators. Faber \& Faber Publisher. ISBN: 0571202284.

Raghav. 2014. What is Animaker? First Look of Do-It-Yourself Animated Video Making App. Animaker. Url: https://www.animaker.com/blog/what-is-animaker/

Anonymous. 2020. What is Kahoot!?. Kahoot!. Url: https://kahoot.com/what-iskahoot/

Fecher, T. 2017. Motion Graphic Desain Academy - The Basics. Free Edition. Germany: Crossfeyer. Url: $\quad$ https://crossfeyer.com/wpcontent/uploads/2018/05/Motion-Graphics-Design-Academy-Free-EditionEbook.pdf

Tonnu, T. 2020. 100 Awesome Motion Graphic Examples You'll Wish You Made. Columnfivemedia. Url: https://www.columnfivemedia.com/best-100motion-graphic-examples 